\title{
A novel flow battery: A lead acid battery based on an electrolyte with soluble lead(II) Part VIII. The cycling of a $10 \mathrm{~cm} \times 10 \mathrm{~cm}$ flow cell
}

\author{
John Collins ${ }^{\mathrm{a}}$, Gareth Kear ${ }^{\mathrm{b}}$, Xiaohong Li ${ }^{\mathrm{b}, *}$, C.T. John Low ${ }^{\mathrm{b}}$, Derek Pletcher ${ }^{\mathrm{c}}$, Ravichandra Tangirala ${ }^{\mathrm{b}}$, \\ Duncan Stratton-Campbell ${ }^{\mathrm{a}}$, Frank C. Walsh ${ }^{\mathrm{b}}$, Caiping Zhang ${ }^{\mathrm{b}}$ \\ a C-Tech Innovation Ltd., Capenhurst, Chester, CH1 6EH, UK \\ ${ }^{\mathrm{b}}$ Energy Technology Research Group, School of Engineering Sciences, University of Southampton, Highfield, University Road, Southampton, SO17 1BJ, UK \\ ${ }^{\mathrm{c}}$ Electrochemistry and Surface Science Group, School of Chemistry, University of Southampton, Southampton, SO17 1BJ, UK
}

\section{A R T I C L E I N F O}

\section{Article history:}

Received 19 June 2009

Received in revised form 13 August 2009

Accepted 17 September 2009

Available online 26 September 2009

\section{Keywords:}

Flow battery

Lead(II) ions

Lead

Lead dioxide

Methanesulfonic acid

Efficiency

\begin{abstract}
A B S T R A C T
The design of a $10 \mathrm{~cm} \times 10 \mathrm{~cm}$ flow cell for the soluble lead acid flow battery is described. A number of extended charge/discharge cycling experiments are presented to demonstrate the capability of the battery to cycle over lengthy periods and to identify the problems that limit the number of cycles that can be achieved. A charge efficiency below 100\%, leading to a build up of deposits on both electrodes and a consequent drop in the concentration of $\mathrm{Pb}^{2+}$ in the electrolyte are found to limit cycle life.
\end{abstract}

(c) 2009 Elsevier B.V. All rights reserved.

\section{Introduction}

In the soluble lead flow battery [1-8], the cell has two inert electrodes and a single electrolyte consisting of a high concentration of lead methanesulfonate (up to $2.5 \mathrm{M}$ ) in methanesulfonic acid is flowed through the interelectrode gap. The electrode reactions are: negative electrode

$\mathrm{Pb}^{2+}+2 \mathrm{e}^{-} \rightleftarrows \mathrm{Pb}$

positive electrode

$\mathrm{Pb}^{2+}+2 \mathrm{H}_{2} \mathrm{O}-2^{\mathrm{e}-} \rightleftarrows \mathrm{PbO}_{2}+4 \mathrm{H}^{+}$

and the overall cell reaction

$2 \mathrm{~Pb}^{2+}+2 \mathrm{H}_{2} \mathrm{O} \underset{\text { discharge }}{\stackrel{\text { charge }}{\rightleftarrows}} \mathrm{Pb}+\mathrm{PbO}_{2}+4 \mathrm{H}^{+}$

The chemistry is different from the traditional lead acid battery in that the electrode reactions do not involve insoluble $\mathrm{Pb}(\mathrm{II})$, i.e., lead sulfate within a paste. The batteries would be expected to have quite different performance characteristics and to find entirely different applications.

\footnotetext{
* Corresponding author. Tel.: +44 2380594905.

E-mail address: Xh.Li@soton.ac.uk(X. Li).
}

In comparison with other flow batteries, the soluble lead battery has the key advantage that it employs only a single electrolyte and therefore operates without a membrane separator. As well as avoiding the cost of a membrane, this simplifies the cell design and halves the number of pumps and reservoirs in the total system. On the other hand, the successful operation of the battery requires the control of the composition and structure of two electrodeposits during charge cycling over a range of current densities and electrolyte compositions. Moreover, significant energy storage necessitates that thick layers $(\approx 1 \mathrm{~mm})$ of $\mathrm{Pb}$ and $\mathrm{PbO}_{2}$ are deposited and dissolved. Earlier papers [1-7] have largely focused on the study of single electrode reaction in conditions that mimic those to be found in the battery. For example, it was reported that lead dendrites were readily formed in the absence of an additive and $\mathrm{C}_{16} \mathrm{H}_{33}\left(\mathrm{CH}_{3}\right)_{3} \mathrm{~N}^{+}$was identified as a stable additive that alleviates this problem [5]. In addition, it has been shown that a small cell with electrodes, $2 \mathrm{~cm} \times 1 \mathrm{~cm}$, could be successfully cycled and a further paper [8] reported some preliminary experiments in two cells with larger electrodes $\left(64 \mathrm{~cm}^{2}\right.$ and $\left.100 \mathrm{~cm}^{2}\right)$.

In this paper we describe in more detail the first stage of scale-up. The flow cell with electrodes, $10 \mathrm{~cm} \times 10 \mathrm{~cm}$, which was fabricated by C-Tech Innovation Ltd., was designed to be operated in a number of configurations. Studies of the hydrodynamics and mass transport regime within the cell including modelling will be published separately [9]. Most experiments used an initial $\mathrm{Pb}(\mathrm{II})$ 
concentration of $0.5 \mathrm{M}$; although a higher concentration [1] is possible $(1.5 \mathrm{M})$ and likely to be used in a practical system, the lower $\mathrm{Pb}$ (II) concentration was employed since it might more rapidly reveal failure modes.

\section{Experimental details}

\subsection{Chemicals}

Lead methanesulfonate $\left(\mathrm{Pb}\left(\mathrm{CH}_{3} \mathrm{SO}_{3}\right)_{2}\right.$, Aldrich, $\left.50 \mathrm{wt} . \%\right)$, methanesulfonic acid $\left(\mathrm{CH}_{3} \mathrm{SO}_{3} \mathrm{H}\right.$, Aldrich, $\left.70 \mathrm{wt} . \%\right)$, lead nitrate $\left(\mathrm{Pb}\left(\mathrm{NO}_{3}\right)_{2}, \mathrm{BDH}, 99 \%\right)$, sodium nitrate $\left(\mathrm{NaNO}_{3}, \mathrm{BDH} 98 \%\right)$, hexadecyltrimethylammonium hydroxide $\left(\mathrm{C}_{16} \mathrm{H}_{33}\left(\mathrm{CH}_{3}\right)_{3} \mathrm{~N}(\mathrm{OH})\right.$, Fluka, $10 \mathrm{wt} . \%)$ were all used as received. All aqueous solutions were freshly prepared with ultra pure water $(18 \mathrm{M} \Omega \mathrm{cm}$ resistivity) from an Elga water purification system.

During battery operation, the lead and acid concentrations in the electrolyte will swing strongly during a charge/discharge cycle, see Eq. (3). With the system employed in these experiments (electrode area $100 \mathrm{~cm}^{2}$, reservoir $1.5 \mathrm{~L}$ ), it was not possible to change the concentration through the full range on a realistic timescale. Hence, most experiments were carried out with a lower lead(II) concentration $(0.5 \mathrm{M})$ than would be used in a real battery; in this way, it is possible to define the battery characteristics with respect to the electrode deposits.

The lead(II) concentrations in the electrolyte were determined using a rotating vitreous carbon disc electrode. The electrolyte was diluted 100 fold with $1 \mathrm{M} \mathrm{NaNO}_{3}$ and voltammograms for the $\mathrm{Pb}^{2+} / \mathrm{Pb}$ reaction were recorded. The slopes of limiting current $v s$. square root of the rotation rate plots were then compared with such plots for standard solutions prepared from crystalline lead nitrate.

\subsection{Flow cell design}

The flow cell and flow circuit, see Fig. 1(a), were designed and built by C-Tech Innovation Ltd. The parallel plate cell, having active electrode areas, $10 \mathrm{~cm} \times 10 \mathrm{~cm}$, was designed to allow operation divided or undivided, with a variable interelectrode gap and a variety of inlet/outlet port patterns; the design also stressed leak free operation and rapid opening/closure to permit observation of electrode deposits etc. In this work the cell was operated only in the undivided mode.

The cell is fabricated from a series of polypropylene blocks $(36 \mathrm{~cm} \times 17 \mathrm{~cm} \times 1 \mathrm{~cm})$, see Fig. 1 (b). The outer blocks had copper plates $(10 \mathrm{~cm} \times 10 \mathrm{~cm} \times 0.3 \mathrm{~cm})$, with current collectors sunk into them so that the surface was flush with the surface of the polymer block. The next blocks housed the electrode materials. Both electrodes were $13 \mathrm{~cm} \times 13 \mathrm{~cm}$ plates which were housed in polypropylene frames with internal dimensions, $13 \mathrm{~cm} \times 13 \mathrm{~cm}$ and the same thicknesses as the electrode plates; the active areas were restricted to $10 \mathrm{~cm} \times 10 \mathrm{~cm} \mathrm{~cm}$ by the frames overlapping the electrodes at the sides and either inlet/outlet ports, Fig. 1(c) or selfadhesive insulating tape (polyester tape, Cole Parmer) in the entry and exit zones. Insulating tape was also used to ensure that the copper current contacts were not exposed to the electrolyte. The electrolyte chamber frame had dimensions $36 \mathrm{~cm} \times 17 \mathrm{~cm} \times 1 \mathrm{~cm}$ and the chamber itself $18 \mathrm{~cm} \times 10 \mathrm{~cm} \times 1 \mathrm{~cm}$, see Fig. 1 (c). The design allowed inlet and outlet flow distributors (polypropylene) to be slotted into the electrolyte frame. This arrangement allowed testing of various designs of distributor including variation of the shape of the inlet/exit zones, the size and number of electrolyte entry/exit slot and the inclusion of turbulence promoters, vanes and current shields. The electrolyte frames had holes drilled into the side so that a 'Luggin tube' could be inserted in order to allow monitoring of the individual electrode potentials $v s$. an $\mathrm{Ag} / \mathrm{AgCl}$ reference electrode. The interelectrode gap could be increased by
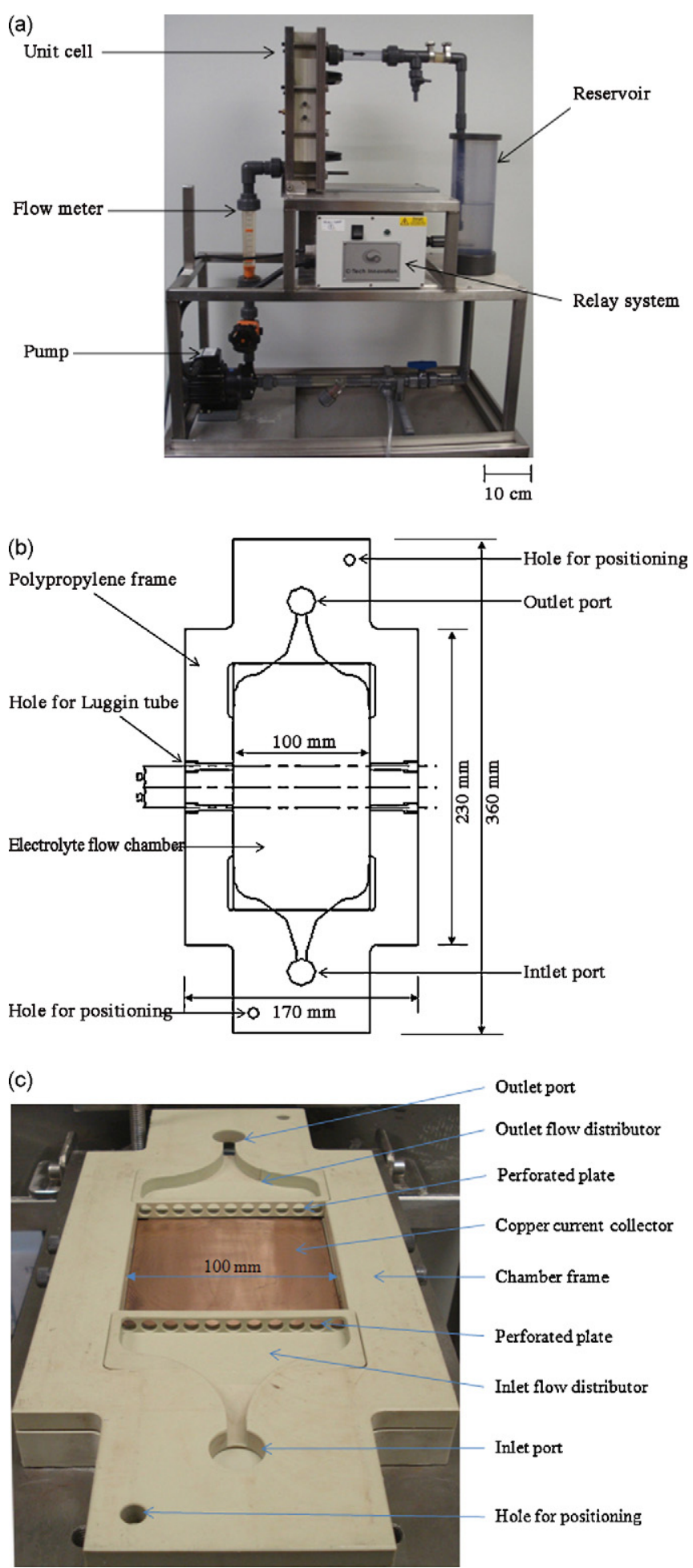

Fig. 1. (a) Photograph of the undivided flow cell and flow circuit which is made up of the cell with active electrode areas of $10 \mathrm{~cm} \times 10 \mathrm{~cm}$, a cylindrical reservoir with a volume up to $2 \mathrm{~L}$, a pump and a flow meter. (b) The polypropylene frame with shaped corners. (c) Photograph of an electrolyte chamber frame with two flow distributors slotted into the inlet and outlet of the frame.

using multiple frames but usually a single frame was employed. Between the electrode frame and the electrolyte compartment, there was an EPDM (Klinger) gasket $(36 \mathrm{~cm} \times 17 \mathrm{~cm} \times 0.1 \mathrm{~cm})$ with $10 \mathrm{~cm} \times 10 \mathrm{~cm}$ sections (with inlet/outlet ports) or $18 \mathrm{~cm} \times 10 \mathrm{~cm}$ sections (without inlet/outlet ports) cut from the centre. 


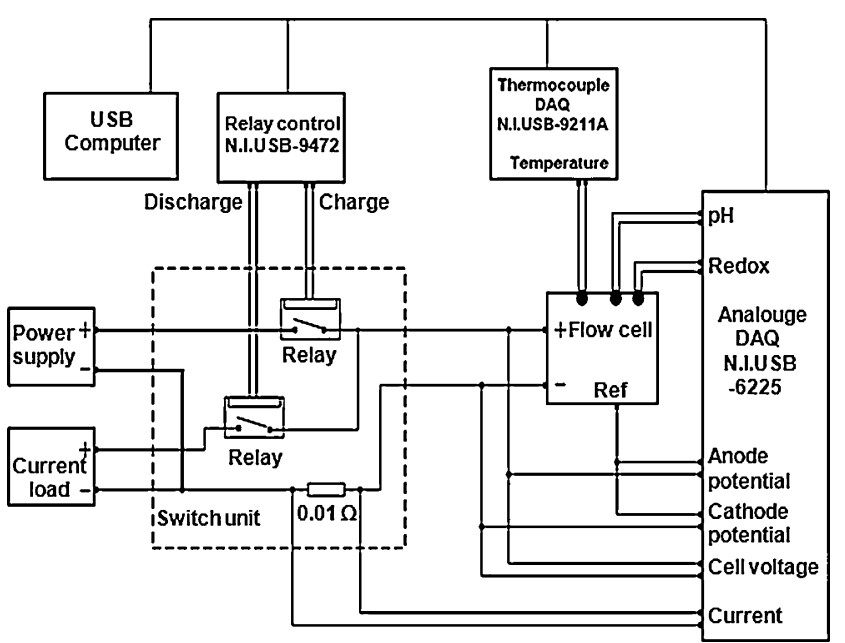

Fig. 2. The automatic controlled system for charging and discharging of the cell and data logging.

The positive electrode was a carbon/polymer composite, either carbon/polyvinyl-ester (Entegris) or carbon/polyvinyldene difluoride (Eisenhuth). The negative electrode was usually nickel (Goodman Alloys) although carbon composites were also used. The cell was clamped between two steel end plates $(36.5 \mathrm{~cm} \times 21 \mathrm{~cm} \times 2 \mathrm{~cm})$ with 8 bolts; one of the plates could be rotated about the bottom to allow rapid and convenient dismantling and reassembly. The flow circuit was interconnected with $2.5 \mathrm{~cm}$ diameter polypropylene pipe, a $2 \mathrm{~L}$, cylindrical reservoir, a magnetically coupled pump (Totton Pumps, type T113095), a flow meter $(100-1000 \mathrm{~L} / \mathrm{h})$ and a flow valve from Georg Fischer $\mathrm{GmbH}$.

In a few experiments, cycling tests were carried out in a smaller flow, parallel plate cell with two carbon/polymer composite electrodes $(2 \mathrm{~cm} \times 2 \mathrm{~cm})$ and entry and exit lengths. The interelectrode gap was $1 \mathrm{~cm}$. The electrolyte volume was $500 \mathrm{~cm}^{3}$, giving a totally different electrode area/solution volume ratio to the $10 \mathrm{~cm} \times 10 \mathrm{~cm}$ cell.

\subsection{Control and data-logging instrumentation}

Four flow cells were operated simultaneously and continuously over extended periods (days or weeks); this necessitated fully automated control and data-logging instrumentation. A personal computer was used to provide the control and data-logging function for all the cells using a number of USB data acquisition and output devices. The control software was written using National Instruments ${ }^{\mathrm{TM}}$ LabVIEW 8.2 graphical programming language. The schematic Fig. 2 shows the set up for each cell. Each cell had a dedicated dc power supply (TSX3510p programmable DC PSU) and electronic load (LD300 DC Electronic Load) from Thurlby Thandar Instruments to permit charging and discharging of the battery at constant current. The power supply and electronic load were manually set before the start of the test and were switched in and out as required by a pair of electromechanical relays which were driven by a USB digital output device (National Instruments USB-9472) controlled by the PC. The experimental data including current, cell voltage, anode potential and cathode potential, redox potential and $\mathrm{pH}$ were recorded via an Analogue National instruments USB Data Acquisition carrier (National Instruments USB-6225) and temperature via a thermocouple USB Data Acquisition carrier (National Instruments USB-9211A), both shared between all the cells. Logged data was processed using standard software (Excel and SigmaPlot 10.0).

\section{Results}

\subsection{Setting the scene}

A cell was set up with a carbon composite positive electrode, a nickel plate negative electrode, an interelectrode gap of $1.2 \mathrm{~cm}$ and no inlet/outlet structures and the electrolyte was $0.5 \mathrm{M}$ $\mathrm{Pb}\left(\mathrm{CH}_{3} \mathrm{SO}_{3}\right)_{2}+0.5 \mathrm{M} \mathrm{CH} \mathrm{SO}_{3} \mathrm{H}+5 \mathrm{mMC}_{16} \mathrm{H}_{33}\left(\mathrm{CH}_{3}\right)_{3} \mathrm{~N}^{+}$(1.5 L). It was then cycled by charging with a current density of $20 \mathrm{~mA} \mathrm{~cm}^{-2}$ for $2 \mathrm{~h}$ followed by discharge at the same current density until the cell voltage dropped to $1.1 \mathrm{~V}$. Fig. 3 illustrates the cell voltage as a function of time during the first 20 cycles. It can be seen that there is a significant difference between the cell voltages on charge and discharge and also that the voltages during charge and discharge are not constant, see later. Fig. 4 reports the charge, voltage and energy efficiencies during this experiment. While these plots show energy efficiencies of $\approx 60 \%$ and no features that would lead to concern about the cell operation, it can be seen that the charge efficiency is always significantly below $100 \%$ so that the cell per-

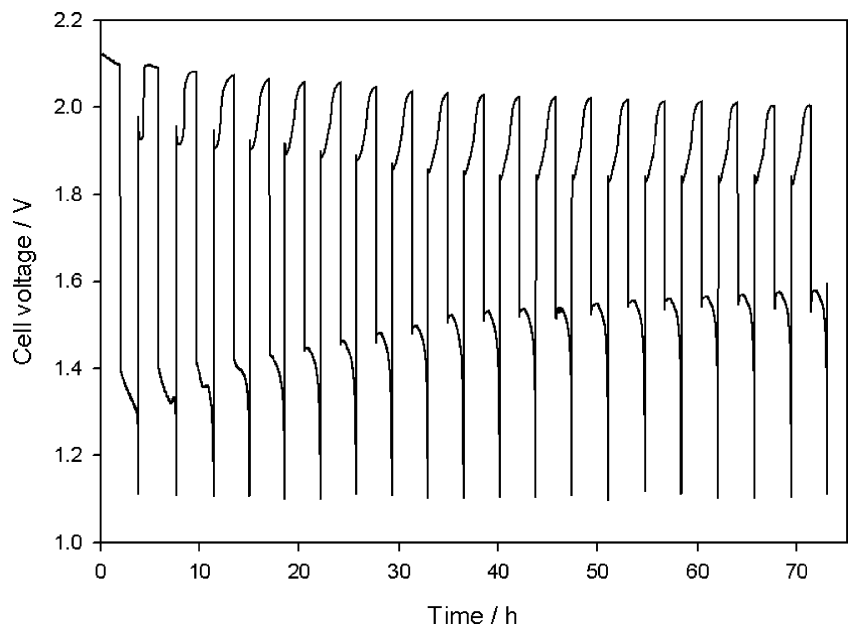

Fig. 3. Cell voltage $v s$. time response for the initial 20 charge/discharge cycles. The cell was charged at $20 \mathrm{~mA} \mathrm{~cm}^{-2}$ for $2 \mathrm{~h}$ and discharged at the same current density until the voltage dropped to $1.1 \mathrm{~V}$ using a carbon/polyvinyl-ester composite positive electrode and a nickel negative electrode with an interelectrode gap $1.2 \mathrm{~cm}$.

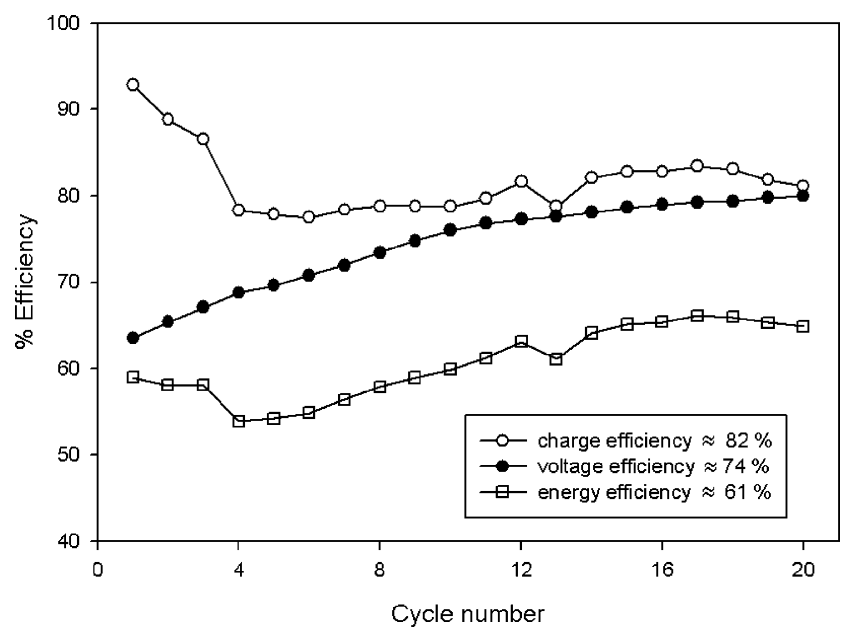

Fig. 4. Cell efficiencies including charge efficiency, voltage efficiency, and energy efficiency during the initial 20 charge/discharge cycles. The cell was charged at $20 \mathrm{~mA} \mathrm{~cm}^{-2}$ for $2 \mathrm{~h}$ and discharged at the same current density until the voltage dropped to $1.1 \mathrm{~V}$ using a carbon/polyvinyl-ester composite positive electrode and a nickel negative electrode with an interelectrode gap $1.2 \mathrm{~cm}$. 


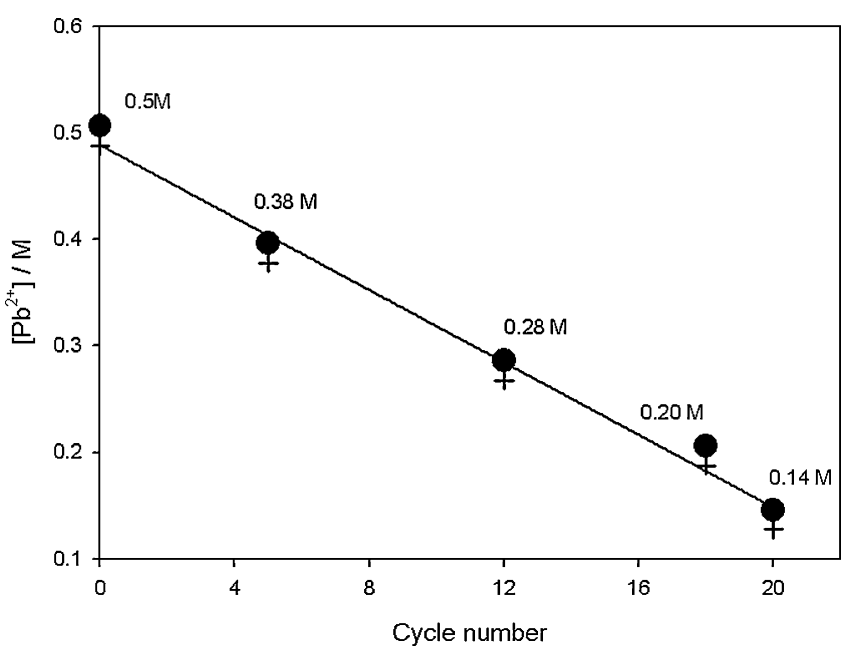

Fig. 5. Change of the $\mathrm{Pb}^{2+}$ concentration during the initial 20 charge/discharge cycles. The cell was charged at $20 \mathrm{mAcm}^{-2}$ for $2 \mathrm{~h}$ and discharged at the same current density until the voltage dropped to $1.1 \mathrm{~V}$ using a carbon/polyvinyl-ester composite positive electrode and a nickel negative electrode with an interelectrode gap $1.2 \mathrm{~cm}$ in an electrolyte solution containing $0.5 \mathrm{M} \mathrm{Pb}\left(\mathrm{CH}_{3} \mathrm{SO}_{3}\right)_{2}+0.5 \mathrm{M}$ $\mathrm{CH}_{3} \mathrm{SO}_{3} \mathrm{H}+5 \mathrm{mMC}_{16} \mathrm{H}_{33}\left(\mathrm{CH}_{3}\right)_{3} \mathrm{~N}^{+}(1.5 \mathrm{~L})$.

formance cannot be explained completely by the chemistry of Eq. (3). Moreover, a fine black precipitate was formed in the electrolyte during charge on the 16th cycle and when the cell was opened at the end of discharge after 20 cycles, solid precipitates were obvious on both electrodes. The deposit on the negative electrode had the appearance of metallic lead while, on the positive electrode, the deposit was made up of fine black particles, largely well adherent to the electrode. We have shown in a previous paper [7] that this positive electrode deposit has a well defined layer by layer structure and $\mathrm{PbO}_{2}$ was the only compound confirmed by X-ray diffraction. It is clear that during each cycle, not all the $\mathrm{PbO}_{2}$ on the positive electrode is reduced. The lead dioxide was scraped from the positive electrode plate, dried and weighed; $60 \mathrm{~g}$ of $\mathrm{PbO}_{2}$ was found and this entirely accounts for the loss in charge efficiency. Clearly, the accumulation of the two solid deposits during the 20 cycles must lead to a drop in $\mathrm{Pb}^{2+}$ concentration in solution. This was confirmed by analysis of the electrolyte at intervals during the 20 cycles, see Fig. 5; the depletion is linear with the number of cycles as expected with an almost constant charge efficiency. While another likely cause of charge inefficiency during cycling is oxygen evolution during charging, in the experiment of Fig. 3 , there is no evidence for this reaction. In fact, in similar experiments, it is seen that if the cycling is continued until the $\mathrm{Pb}^{2+}$ concentration drops to a very low value, oxygen evolution leads to cell voltage spikes to higher voltage in the cell voltage $v s$. time plot during charge and the charge efficiency drops further. During more extended cycling, a further problem was identified; spikes in the cell voltage vs. time plot to lower cell voltage were observed and this could be associated with shorting of the electrodes due to lead dendrites commonly around the edges of the negative electrode plate. Such dendrites could be seen on opening the cell but only occurred when the $\mathrm{Pb}^{2+}$ concentration had dropped to below $0.1 \mathrm{M}$.

Fig. 6 shows an expansion of the cell voltage vs. time plot for the first two cycles as well as the individual electrode potentials monitored $v s$. an $\mathrm{Ag} / \mathrm{AgCl}$ reference electrode. A number of features should be noted.

(i) The cell voltage during the first charge is almost constant at $\approx 2.05 \mathrm{~V}$ but during the second charge, the cell voltage commences at a lower value, $\approx 1.85 \mathrm{~V}$, and increases back to $2.05 \mathrm{~V}$ only after $1 \mathrm{~h}$. This shift is also seen in the positive electrode

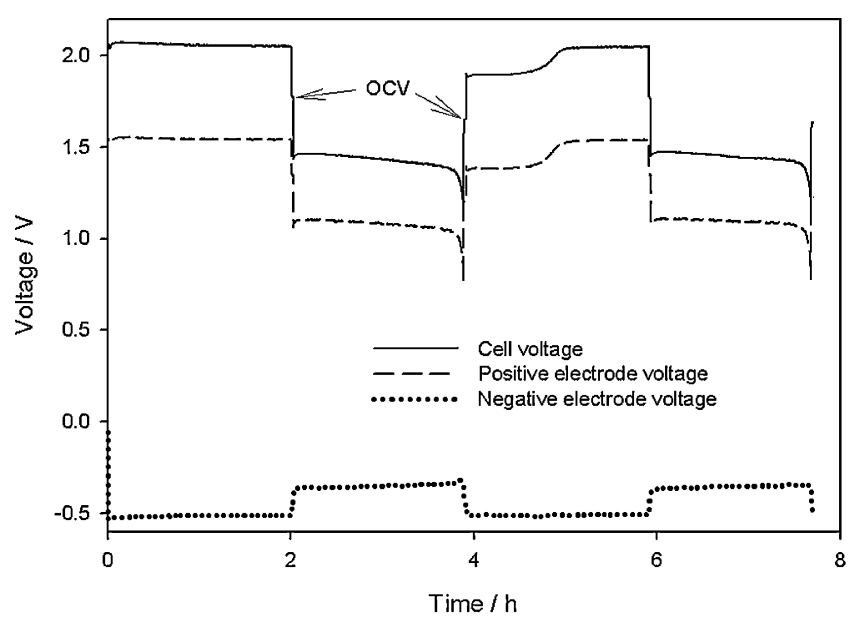

\begin{tabular}{|c|c|c|}
\hline \multirow{2}{*}{$1^{\text {st }}$ cycle } & \multicolumn{2}{|c|}{ Open circuit voltage $(\mathrm{V})$} \\
\cline { 2 - 3 } Cell voltage & At the end of charge & At the end of discharge \\
\hline Positive electrode & 1.78 & 1.64 \\
\hline Negative electrode & 1.35 & 1.22 \\
\hline
\end{tabular}

Fig. 6. Cell voltage vs. time response for the first two charge/discharge cycles as well as the individual electrode potentials monitored $v$ s. an $\mathrm{Ag} / \mathrm{AgCl}$ reference electrode. The cell was charged at $20 \mathrm{mAcm}^{-2}$ for $2 \mathrm{~h}$ and discharged at the same current density until the voltage dropped to $1.1 \mathrm{~V}$ using a carbon/polyvinyl-ester composite positive electrode and a nickel negative electrode with an interelectrode gap $1.2 \mathrm{~cm}$ in an electrolyte solution containing $0.5 \mathrm{M} \mathrm{Pb}\left(\mathrm{CH}_{3} \mathrm{SO}_{3}\right)_{2}+0.5 \mathrm{M}$ $\mathrm{CH}_{3} \mathrm{SO}_{3} \mathrm{H}+5 \mathrm{mMC} \mathrm{C}_{16} \mathrm{H}_{33}\left(\mathrm{CH}_{3}\right)_{3} \mathrm{~N}^{+}(1.5 \mathrm{~L})$.

potential confirming that it is associated with the deposition of lead dioxide. This phenomenon has been reported earlier [1-3,7] and indicates a mechanism for $\mathrm{PbO}_{2}$ formation with more favourable thermodynamics and/or kinetics and hence either a more advantageous reactant than $\mathrm{Pb}^{2+}$ in solution, a change in local electrolyte composition or a more favourable surface for deposition during the early part of the charging process. It has not been possible to identify any deposit other than $\mathrm{PbO}_{2}$ at the end of discharge and the long interval before the increase in voltage make a change in surface an unlikely explanation. The most probable explanation is a change in local electrolyte composition. It is known that during discharge of lead acid batteries, within the positive electrode paste, the $\mathrm{pH}$ can rise to 9 despite the highly acidic electrolyte. A similar shift in the $\mathrm{PbO}_{2}$ layer within the soluble lead acid flow battery would lead to the observed voltage shifts. The equilibrium potential for reaction (2) is given by

$E_{\mathrm{oc}}=\Delta E_{\mathrm{e}}^{\mathrm{o}}+\frac{2.3 R T}{2 F} \log \frac{\left[\mathrm{H}^{+}\right]^{4}}{\left[\mathrm{~Pb}^{2+}\right]^{2}}$

It can be seen that the equilibrium potential will shift in the negative direction as acid starvation occurs during discharge and also shift positive as reaction (2) again generates acid during charge.

(ii) The main overpotential and voltage inefficiency is confirmed to arise at the positive electrode, i.e. they are associated with the $\mathrm{Pb}^{2+} / \mathrm{PbO}_{2}$ couple.

(iii) The open circuit potentials at the end of charge and discharge can be seen to be $+1.78 \mathrm{~V}$ and $+1.64 \mathrm{~V}$, respectively and the difference arises from changes to both $\mathrm{Pb}^{2+}$ and $\mathrm{H}^{+}$concentrations in solution with state of charge, see Eq. (4). The value at the end of discharge, however, shows that $\mathrm{PbO}_{2}$ is still determining the potential of the positive electrode. In fact changing the final cell voltage to terminate discharge from $+1.1 \mathrm{~V}$ to $+0.5 \mathrm{~V}$ 
or even $0.0 \mathrm{~V}$ caused only a very small increase in the charge obtained from the cell.

Returning to Fig. 3, another feature of note is the increase in voltage efficiency from $64 \%$ to $80 \%$ over the 20 cycles owing to two improvements - the voltage decreases during charge and increases during discharge. This trend is seen in all experiments. Moreover, the change is too large to be explained on the basis of a decrease in interelectrode gap. By monitoring the individual electrode potentials, it is clear that the improvement is associated with the performance of the positive electrode. The overpotentials decrease for both deposition and reduction of $\mathrm{PbO}_{2}$ with cycling. Since this change is accompanied by a change of structure leading to a more rougher, porous and poorly adherent deposit, a possible explanation is an increase in the surface area or porosity of the $\mathrm{PbO}_{2}$ layer. Furthermore, it is possible that changes in the electrode surface may be responsible for the gradual decrease in charging voltage. As shown in Fig. 3, the voltage spike associated with nucleation disappears as the charging voltage decreases. Nucleation effects are clearly visible during the initial charge cycles. The spikes in the voltage-time curves gradually disappear with each cycle as the increasing amount of residual solid on the electrode surface provides active sites for subsequent nucleation.

\subsection{The influence of cell design}

Early in the programme, a number of inlet/outlet structures were tested with a view to obtaining uniform electrolyte flow through the interelectrode gap; these experiments again used a solution containing $0.5 \mathrm{M} \mathrm{Pb}\left(\mathrm{CH}_{3} \mathrm{SO}_{3}\right)_{2}+0.5 \mathrm{M}$ $\mathrm{CH}_{3} \mathrm{SO}_{3} \mathrm{H}+5 \mathrm{mMC}_{16} \mathrm{H}_{33}\left(\mathrm{CH}_{3}\right)_{3} \mathrm{~N}^{+}$and were cycled by charging with a current density of $20 \mathrm{~mA} \mathrm{~cm}^{-2}$ for $2 \mathrm{~h}$ followed by discharge at the same current density until the cell voltage dropped to $1.1 \mathrm{~V}$. Fig. 7 is a photograph taken after 30 cycles to illustrate a general problem. In this experiment, the electrolyte entry and exit were through a number of holes in polymer distributors placed immediately below and above the active electrode areas. It can be seen that black material surrounds the holes. X-ray diffraction shows that the deposit is $\mathrm{PbO}_{2}$ and it is hard and reflective. It does not appear to be made up of compacted powdery material and it was concluded that it is not formed by particles of $\mathrm{PbO}_{2}$ falling off the electrode but by the electrodeposit creeping away from the positive electrode and across the polymer surface. Indeed, a similar phenomenon was sometimes observed across the sides of the polymer electrolyte chamber and at any points where there is a sharp change of section

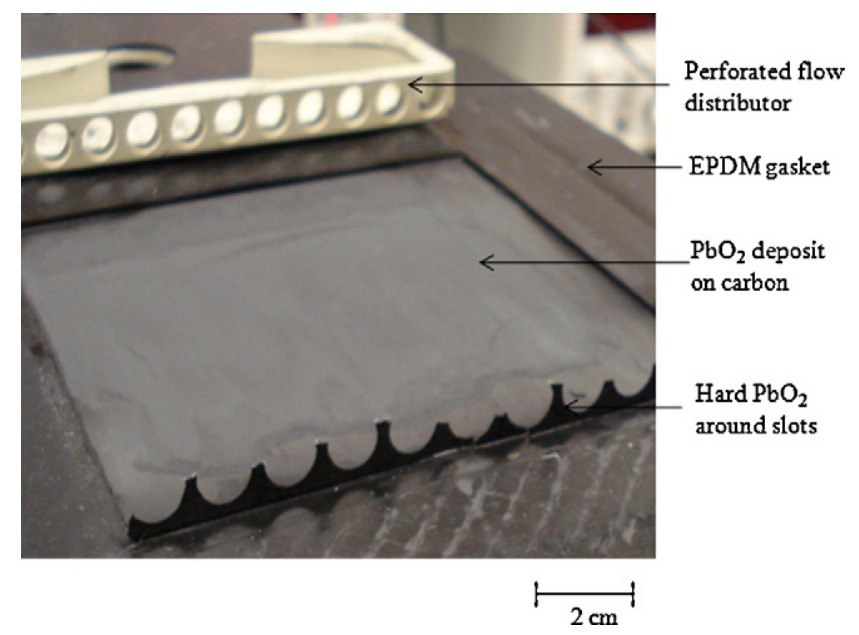

Fig. 7. The hard $\mathrm{PbO}_{2}$ deposit formed around the slots of an electrolyte distributor. The picture also shows the distributor after its removal.

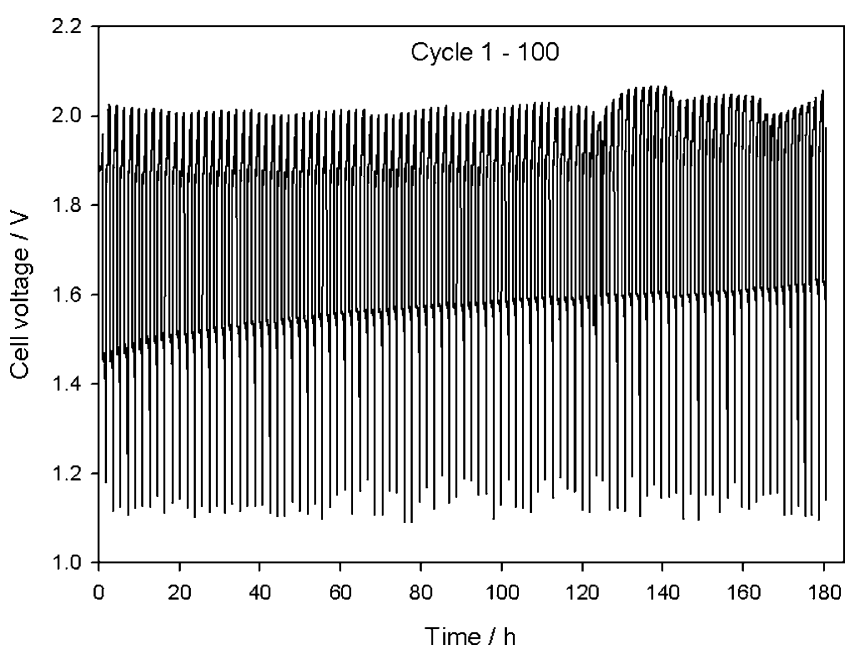

Fig. 8. Cell voltage $v s$. time response for 100 charge/discharge cycles. The cell was charged at $20 \mathrm{mAcm}^{-2}$ for $1 \mathrm{~h}$ and discharged at the same current density until the voltage dropped to $1.1 \mathrm{~V}$ using a carbon/polyvinyl-ester composite positive electrode and a nickel negative electrode with an interelectrode gap $1.2 \mathrm{~cm}$ in an electrolyte solution initially containing $0.5 \mathrm{M} \mathrm{Pb}\left(\mathrm{CH}_{3} \mathrm{SO}_{3}\right)_{2}+0.5 \mathrm{M}$ $\mathrm{CH}_{3} \mathrm{SO}_{3} \mathrm{H}+5 \mathrm{mMC} \mathrm{C}_{16} \mathrm{H}_{33}\left(\mathrm{CH}_{3}\right)_{3} \mathrm{~N}^{+}(1.5 \mathrm{~L})$. During cycling the fresh $\mathrm{Pb}\left(\mathrm{CH}_{3} \mathrm{SO}_{3}\right)_{2}$ solution was added periodically in order to keep the $\mathrm{Pb}^{2+}$ concentration in the electrolyte to $0.5 \mathrm{M}$.

and/or flow at the interface of the positive electrode. Hence, later experiments were all carried out without any inlet or outlet structure close to the active electrode area and insulating tape masking the perimeter of the two electrodes.

Further experiments showed that (a) the mean linear flow rate was doubled from $2.3 \mathrm{~cm} \mathrm{~s}^{-1}$ to $4.6 \mathrm{~cm} \mathrm{~s}^{-1}$ without change to the cell performance. (b) Increasing the interelectrode gap from $1.2 \mathrm{~cm}$ to $2.4 \mathrm{~cm}$ led to a substantial increase in the number of cycles before shorting of the cell led to failure. This, however, increased the IR drop and lowered the voltage efficiency and was therefore not a commonly used approach. (c) Increasing the volume of electrolyte in the reservoir so as decrease the electrode area/solution volume greatly increased the number of cycles that could be achieved. For example, doubling the electrolyte volume allowed 100 cycles to be achieved. This improvement with electrolyte volume probably arises because of the slower change in $\mathrm{Pb}^{2+}$ concentration.

\subsection{Maintaining the lead(II) concentration}

Low $\mathrm{Pb}^{2+}$ concentrations in the electrolyte appear to lead both to $\mathrm{O}_{2}$ evolution during charge and the formation of lead dendrites on the negative electrode. Hence, a series of cycling experiments were carried out to test the cell performance with the $\mathrm{Pb}^{2+}$ concentration maintained constant. Using the initial electrolyte, $0.5 \mathrm{M}$ $\mathrm{Pb}\left(\mathrm{CH}_{3} \mathrm{SO}_{3}\right)_{2}+0.5 \mathrm{M} \mathrm{CH}_{3} \mathrm{SO}_{3} \mathrm{H}+5 \mathrm{mMC}_{16} \mathrm{H}_{33}\left(\mathrm{CH}_{3}\right)_{3} \mathrm{~N}^{+}$and additions of $\mathrm{Pb}\left(\mathrm{CH}_{3} \mathrm{SO}_{3}\right)_{2}$ were made every 10 cycles in order to return the $\mathrm{Pb}^{2+}$ concentration in the electrolyte to $0.5 \mathrm{M}$. The current density was maintained at $20 \mathrm{~mA} \mathrm{~cm}^{-2}$ during both charge and discharge and the cut off voltage for discharge was $1.1 \mathrm{~V}$. The results should be compared with experiments where no $\mathrm{Pb}\left(\mathrm{CH}_{3} \mathrm{SO}_{3}\right)_{2}$ additions were made after the commencement of the experiment; then a decrease in charge efficiency and erratic changes in cell voltage during charge (due to $\mathrm{O}_{2}$ evolution and/or cell shorting) were observed after 15-30 cycles.

In the first experiment, the charge time was limited to $1 \mathrm{~h}$ when the cell performed well. In fact, the experiment was terminated after 100 cycles when the cell voltage $v s$. time response appeared to have reached a steady state without any voltage oscillations, see Fig. 8 . The charge efficiency remained above $80 \%$ and the voltage efficiency was $83 \%$. When the experiment was repeated with a $2 \mathrm{~h}$ 


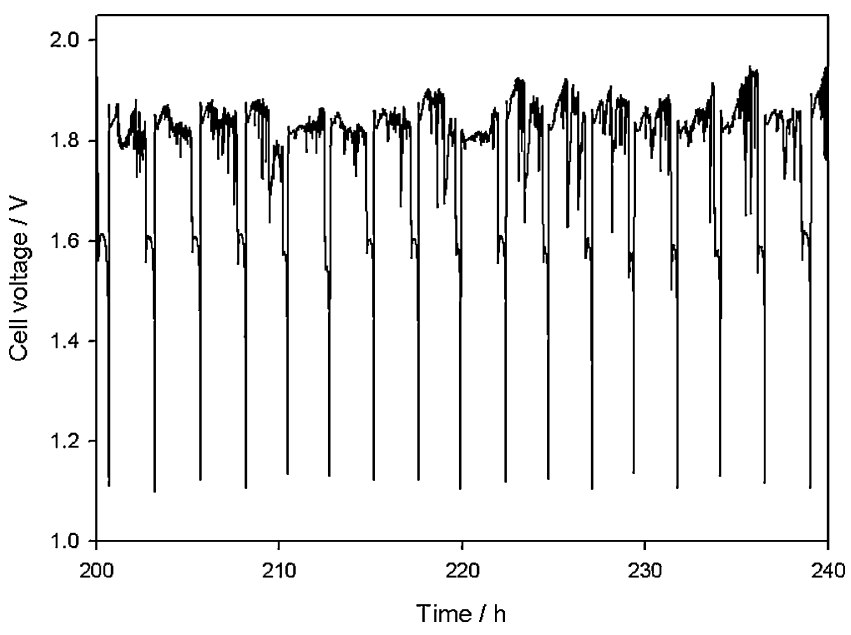

Fig. 9. Cell voltage $v s$. time response for the 61 st-77th charge/discharge cycles. The cell was charged at $20 \mathrm{mAcm}^{-2}$ for $2 \mathrm{~h}$ and discharged at the same current density until the voltage dropped to $1.1 \mathrm{~V}$ using a carbon/polyvinyl-ester composite positive electrode and a nickel negative electrode with an interelectrode gap $1.2 \mathrm{~cm}$ in an electrolyte solution initially containing $0.5 \mathrm{M} \mathrm{Pb}\left(\mathrm{CH}_{3} \mathrm{SO}_{3}\right)_{2}+0.5 \mathrm{M}$ $\mathrm{CH}_{3} \mathrm{SO}_{3} \mathrm{H}+5 \mathrm{mMC}_{16} \mathrm{H}_{33}\left(\mathrm{CH}_{3}\right)_{3} \mathrm{~N}^{+}(1.5 \mathrm{~L})$. During cycling the fresh $\mathrm{Pb}\left(\mathrm{CH}_{3} \mathrm{SO}_{3}\right)_{2}$ solution was added periodically in order to keep the $\mathrm{Pb}^{2+}$ concentration in the electrolyte to $0.5 \mathrm{M}$.

charge time with a consequent deposition of thicker layers on both electrodes, good performance was observed up to 50 cycles and it was possible to achieve 80 cycles. Fig. 9 illustrates the cell voltage $v s$. time response towards the end of the experiment, in fact cycles 61-77. Some voltage oscillations resulting from shorting are observed and, indeed, these were observed as early as the 40th cycle. Although in the first 20 cycles, the charge efficiency is high, $>80 \%$, by the 80 th cycle, it had dropped to $\approx 20 \%$.

Clearly, maintaining the lead(II) concentration close to $0.5 \mathrm{M}$ allows more extended cycling of the cell. It cannot be a complete solution since it does not stop the build up of deposits on the electrodes. This was readily confirmed by eye when the cells were opened. With the shorter charge time, the thickness of the deposits will be less and hence more complete reduction of the $\mathrm{PbO}_{2}$ is likely [7] resulting in less build up of material on the two electrodes.

\subsection{Current and charge density}

In this cell system, where the limitations arise from uneven deposition during charge and therefore the concentration of lead(II) in the electrolyte, the current density, the length of charge periods and the initial concentration of $\mathrm{Pb}^{2+}$ are interlinked parameters. This was further confirmed in a series of experiments using a cell with a carbon composite positive electrode, a nickel negative electrode, an interelectrode gap of $1.2 \mathrm{~cm}$ and no inlet/outlet structures and the electrolyte was $0.5 \mathrm{M} \mathrm{Pb}\left(\mathrm{CH}_{3} \mathrm{SO}_{3}\right)_{2}+0.5 \mathrm{M}$ $\mathrm{CH}_{3} \mathrm{SO}_{3} \mathrm{H}+5 \mathrm{mMC}_{16} \mathrm{H}_{33}\left(\mathrm{CH}_{3}\right)_{3} \mathrm{~N}^{+}(1.5 \mathrm{~L})$ and no $\mathrm{Pb}^{2+}$ additions were made, see Table 1.

In the first experiment, the current density was $10 \mathrm{~mA} \mathrm{~cm}^{-2}$ during both charge and discharge and the charge period was $1 \mathrm{~h}$. Charge cycling could be continued for 164 cycles before any spikes were seen in the cell voltage $v s$. time plots. During most of the experiment, a steady state response was seen, see Fig. 10, with a charge efficiency of $94 \%$ and a voltage efficiency of $86 \%$. In the following two experiments, the current density was increased to $20 \mathrm{~mA} \mathrm{~cm}^{-2}$ and $30 \mathrm{~mA} \mathrm{~cm}^{-2}$ when there was a decrease in the number of cycles possible before cell voltage oscillations were recorded, see Table 1. While a trend to less uniform deposits with increasing current density is to be expected, the more important factor here is almost certainly that the $\mathrm{Pb}^{2+}$ in the electrolyte is depleted more rapidly
Table 1

Performance of soluble lead acid flow cell as a function of current density and charge time.

\begin{tabular}{llll}
\hline $\begin{array}{l}\text { Current density } \\
\left(\mathrm{mAcm}^{-2}\right)\end{array}$ & $\begin{array}{l}\text { Number of cycles } \\
\text { before voltage } \\
\text { spikes }\end{array}$ & $\begin{array}{l}\text { \% Average charge } \\
\text { efficiency }\end{array}$ & $\begin{array}{l}\text { \% Average voltage } \\
\text { efficiency }\end{array}$ \\
\hline 1-h charge & 164 & 94 & 86 \\
10 & 40 & 88 & 74 \\
20 & 19 & 86 & 70 \\
30 & 23 & 81 & 77 \\
2-h charge & 18 & 82 & 64 \\
20 & & & \\
30 & & 82 & 70 \\
\hline
\end{tabular}

Carbon composite positive electrode, a nickel negative electrode, an interelectrode gap of $1.2 \mathrm{~cm}$ and no inlet/outlet structures in cell. Electrolyte: $0.5 \mathrm{M}$ $\mathrm{Pb}\left(\mathrm{CH}_{3} \mathrm{SO}_{3}\right)_{2}+0.5 \mathrm{M} \mathrm{CH}_{3} \mathrm{SO}_{3} \mathrm{H}+5 \mathrm{mMC}_{16} \mathrm{H}_{33}\left(\mathrm{CH}_{3}\right)_{3} \mathrm{~N}^{+}(1.5 \mathrm{~L})-$ no $\mathrm{Pb}^{2+}$ additions were made. The same current density was used on charge and discharge.

with increasing current density. In addition, the charge efficiency and the voltage efficiency decline. The voltage efficiency drops because of increases in overpotential and IR drops. The predominant factor determining the decrease in charge efficiency with increasing current density is probably the increase in deposit thickness (from $\approx 0.1 \mathrm{~mm}$ to $\approx 0.3 \mathrm{~mm}$ ); we have shown previously [7] that the charge efficiency for the reduction of $\mathrm{PbO}_{2}$ decreases with increasing thickness of the layer.

For two current densities, the charge time is doubled (also see Table 1). The cell performance worsens, most markedly with respect to the number of cycles before shorting is observed. Again, the most important factor will be the greater removal of $\mathrm{Pb}^{2+}$ although the trends to a lower charge efficiency with increasing $\mathrm{PbO}_{2}$ layer thickness and to a rougher deposit with increasing current density may also contribute.

In order to increase our understanding of the influences of current density and charge time without the effects of changes in $\mathrm{Pb}^{2+}$ concentration in the electrolyte, a few experiments were carried out in a smaller parallel plate cell with $4 \mathrm{~cm}^{2}$ electrodes, see Table 2 . An important difference in the cells is the ratio of electrode area to electrolyte volume, namely $1 \mathrm{~cm}^{2}: 125 \mathrm{~cm}^{3}$ the small cell compared to $1 \mathrm{~cm}^{2}: 15 \mathrm{~cm}^{3}$ in the $10 \times 10 \mathrm{~cm}$ electrode cell. The electrolyte was $0.5 \mathrm{M} \mathrm{Pb}\left(\mathrm{CH}_{3} \mathrm{SO}_{3}\right)_{2}+0.3 \mathrm{M} \mathrm{CH}_{3} \mathrm{SO}_{3} \mathrm{H}+5 \mathrm{mMC}_{16} \mathrm{H}_{33}\left(\mathrm{CH}_{3}\right)_{3} \mathrm{~N}^{+}$. It is also likely that the flow and current distributions are more uniform in the smaller flow cell. In the first experiments, the cur-

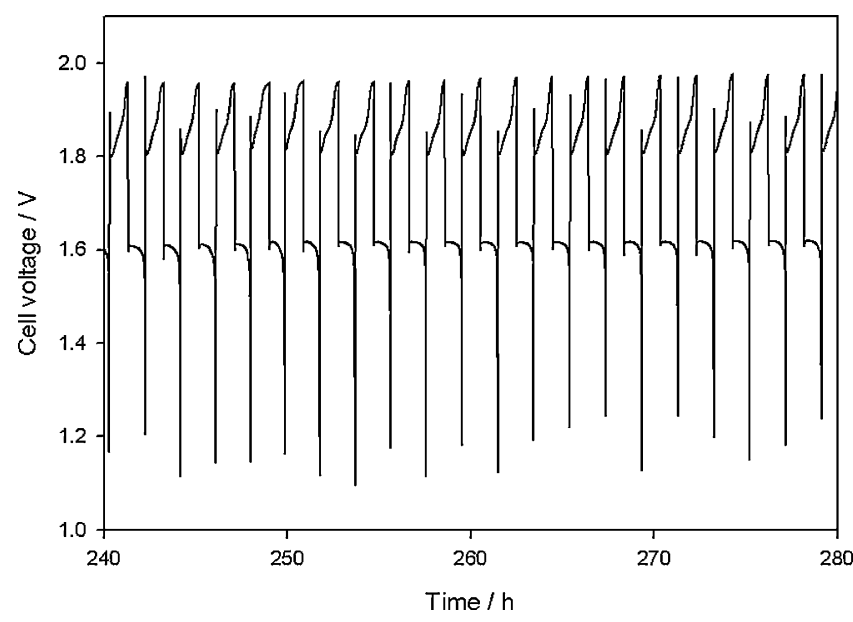

Fig. 10. Cell voltage $v s$. time response for the 121st-140th charge/discharge cycles. The cell was charged at $10 \mathrm{mAcm}^{-2}$ for $1 \mathrm{~h}$ and discharged at the same current density until the voltage dropped to $1.1 \mathrm{~V}$ using a carbon/polyvinyl-ester composite positive electrode and a nickel negative electrode with an interelectrode gap $1.2 \mathrm{~cm}$ in an electrolyte solution containing $0.5 \mathrm{M} \mathrm{Pb}\left(\mathrm{CH}_{3} \mathrm{SO}_{3}\right)_{2}+0.5 \mathrm{M}$ $\mathrm{CH}_{3} \mathrm{SO}_{3} \mathrm{H}+5 \mathrm{mMC}_{16} \mathrm{H}_{33}\left(\mathrm{CH}_{3}\right)_{3} \mathrm{~N}^{+}(1.5 \mathrm{~L})$. 
Table 2

Data from $2 \mathrm{~cm} \times 2 \mathrm{~cm}$ parallel plate cell with two carbon/polymer composite electrodes to show the possibility of operation at higher current density and longer charge time.

\begin{tabular}{llll}
\hline $\begin{array}{l}\text { Current density } \\
\left(\mathrm{mAcm}^{-2}\right)\end{array}$ & $\begin{array}{l}\text { Charge } \\
\text { time }(\mathrm{h})\end{array}$ & $\begin{array}{l}\text { \% Charge } \\
\text { efficiency }\end{array}$ & $\begin{array}{l}\text { \% Voltage } \\
\text { efficiency }\end{array}$ \\
\hline 20 & 2 & 85 & 68 \\
20 & 4 & 75 & 72 \\
20 & 6 & 80 & 71 \\
80 & 1 & 92 & 40 \\
\hline
\end{tabular}

Electrolyte: $0.5 \mathrm{M} \mathrm{Pb}\left(\mathrm{CH}_{3} \mathrm{SO}_{3}\right)_{2}+0.3 \mathrm{M} \mathrm{CH}_{3} \mathrm{SO}_{3} \mathrm{H}+5 \mathrm{mMC}_{16} \mathrm{H}_{33}\left(\mathrm{CH}_{3}\right)_{3} \mathrm{~N}^{+}(0.5 \mathrm{~L})$.

rent density was maintained at $20 \mathrm{mAcm}^{-2}$ but the charge time was extended to $6 \mathrm{~h}$ to give much thicker deposits on both electrodes. In fact, the charge time was increased sequentially $(0.5$, $1,2,34,6 \mathrm{~h}-10$ cycles at each charge time) with only a single physical clean of the electrodes (at the end of the $4 \mathrm{~h}$ charges). The cell voltage $v s$. time plots remained smooth without evidence for electrode shorting or oxygen evolution. In addition, the charge and voltage efficiencies showed no tendency to decline during each 10 cycles and little trend with charge time. In a further experiment, the current density was increased to $80 \mathrm{mAcm}^{-2}$ during both charge and discharge; during the 10 cycles recorded, there was no degradation in charge performance although the voltage efficiency is diminished by the high IR drop in the cell.

\subsection{Partial discharge cycling}

In all the experiments reported so far in this paper, the soluble lead acid flow battery has been deep discharged on every cycle. This is not the optimum regime for many batteries and the performance of many battery systems, including commercial lead acid batteries, are known to be superior if the electrodes are not fully discharged. Hence, two further experiments with partial discharge on each cycle were carried out with the soluble lead acid flow battery.

In each experiment, the current density was $20 \mathrm{mAcm}^{-2}$. The cell was initially charged for $2 \mathrm{~h}$, then discharged until the voltage dropped to $1.1 \mathrm{~V}$ before being again charged for $2 \mathrm{~h}$. In the first experiment, the cell was then subjected to a cycle regime consisting of (a) discharge for $30 \mathrm{~min}$ or to a cut off voltage of $+0.5 \mathrm{~V}$ if this is reached before $30 \mathrm{~min}$ of discharge (b) charge for $30 \mathrm{~min}$. In the second experiment, the cycle time was increased to $1 \mathrm{~h}$ charge/ $1 \mathrm{~h}$ discharge. Fig. 11 compares the charge efficiency as a function of

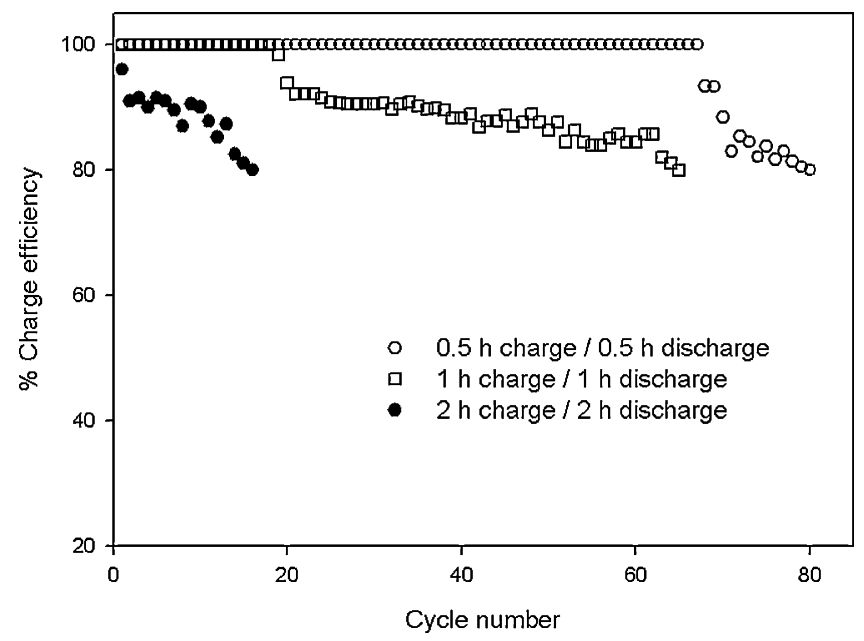

Fig. 11. Charge efficiency as a function of cycle number for three charge and discharge regime where the depth of discharge is varied. See text for details of the regimes. Current density: $20 \mathrm{mAcm}^{-2}$. Electrolyte: $0.5 \mathrm{M} \mathrm{Pb}\left(\mathrm{CH}_{3} \mathrm{SO}_{3}\right)_{2}+0.5 \mathrm{M}$ $\mathrm{CH}_{3} \mathrm{SO}_{3} \mathrm{H}+5 \mathrm{mMC}_{16} \mathrm{H}_{33}\left(\mathrm{CH}_{3}\right)_{3} \mathrm{~N}^{+}(1.5 \mathrm{~L})$.

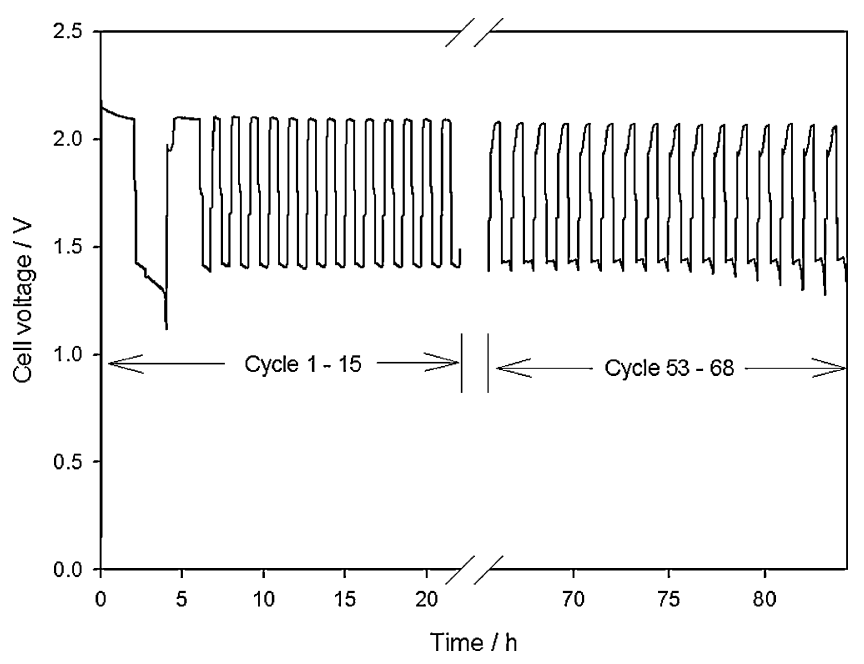

Fig. 12. Cell voltage vs. time responses during an experiment with charge and discharge at $20 \mathrm{mAcm}^{-2}$ but with discharge only to $25 \%$ of the electroactive materials on the electrodes. Electrolyte: $0.5 \mathrm{M} \mathrm{Pb}\left(\mathrm{CH}_{3} \mathrm{SO}_{3}\right)_{2}+0.5 \mathrm{M}$ $\mathrm{CH}_{3} \mathrm{SO}_{3} \mathrm{H}+5 \mathrm{mMCC}_{16} \mathrm{H}_{33}\left(\mathrm{CH}_{3}\right)_{3} \mathrm{~N}^{+}(1.5 \mathrm{~L})$.

cycle number for these two experiments with that where deep discharge has been allowed. With the $30 \mathrm{~min}$ charge/30 min discharge regime, the charge efficiency is $100 \%$ for the first 67 cycles before decaying slowly. With increasing depth of discharge, the decay in charge efficiency occurs much more rapidly and, indeed, in deep discharge experiments, the charge efficiency is never $100 \%$. The improvement in performance with shallower discharge is also evident since the black precipitate in solution was much slower to form and voltage oscillations during charge were absent for many more cycles. Moreover, then the experiments were terminated and the cell opened for inspection, the deposits on the electrodes were both thinner and more uniform with shallower discharge.

Another interesting observation was made during these experiments. Fig. 12 reports the voltage/time responses during the cycling of the battery using $30 \mathrm{~min}$ charge/30 min discharge regime. During the initial cycles the response is 'square' with both charge and discharge voltages constant; but, the charge voltage is above $2.0 \mathrm{~V}$. In the later cycles, cycles 50-68, there is some decay in the cell voltage during discharge and during the charge periods, the voltage is initially $\approx 1.90 \mathrm{~V}$ before increasing again to above $2.0 \mathrm{~V}$. Moreover, the departure from a 'square' response becomes more pronounced with cycle number. The same trend in the shape of the voltage/time response is seen with the $1 \mathrm{~h}$ charge/ $1 \mathrm{~h}$ discharge regime but the movement away from a 'square' response occurs much sooner, after approximately 10 cycles. It can be concluded that the changes to the voltage during charge are tied to those (and probably result from) the changes during discharge. Moreover, the changes to the response depend on the depth of discharge.

\section{Discussion}

It has been demonstrated that extended cycling of the soluble lead acid battery in a $10 \mathrm{~cm} \times 10 \mathrm{~cm}$ parallel plate cell is possible, with $>100$ cycles achieved under some conditions. Eventual failure is, however, inevitable if the battery is operated under conditions where solids are allowed to accumulate continuously on the two electrodes. Failure usually results from: (a) shorting of the electrodes owing to lead dendrites formation largely around the edges of the negative electrode plate and (b) poor adhesion of $\mathrm{PbO}_{2}$ to the positive electrode surface leading to particles in the electrolyte and loss of active material.

Cell performance can also be degraded by oxygen evolution during charge. In general, these unwanted phenomena occur much 
more rapidly when the concentration of $\mathrm{Pb}^{2+}$ in the electrolyte drops below a critical level. Provided the $\mathrm{Pb}^{2+}$ concentration is maintained above this level, the hexadecyltrimethylammonium cation additive appears to be able to control the structure of lead deposit on the negative electrode and the lead dioxide deposit on the positive electrode remains a coherent and adherent layer. Indeed, some loss of $\mathrm{PbO}_{2}$ from the positive electrode does not lead to disastrous failure but the problem gets worse with continued cycling. While 'creepage' of the $\mathrm{PbO}_{2}$ deposit over non-conducting surfaces adjacent to the active electrode area is an additional problem, this can be controlled by avoiding structures in the cell design that would support such material. Significant oxygen evolution during charge does not occur early in the cell life and can be avoided by control of the electrolyte composition.

The decrease in $\mathrm{Pb}^{2+}$ concentration in the electrolyte with battery cycling results from the deposition of solids on both electrodes, $\mathrm{Pb}$ metal on the negative electrode and $\mathrm{PbO}_{2}$ on the positive electrode, that is not removed at the end of each charge/discharge cycle. With deep discharge, the charge efficiency during each charge/discharge cycle is always below $100 \%$ and can be as low as $80 \%$ and this appears to be a consequence of incomplete reduction of the $\mathrm{PbO}_{2}$ layer. This incomplete reduction of the $\mathrm{PbO}_{2}$ was the focus of an earlier paper [7] where it was concluded that it results from acid starvation within the pores of the layer. As the $\mathrm{pH}$ rises, the potential required for reduction of the $\mathrm{PbO}_{2}$ shifts negative (see Eq. (4)), consistent with the observed cell voltage $v$ s. time responses during discharge; this shift could be large since in the lead acid battery it has been estimated that within the paste the $\mathrm{pH}$ increases to 9 despite the concentrated sulfuric acid electrolyte. This explanation is also consistent with the observations during cycling that the charge efficiency gets worse with the charge time (i.e. thickness of the deposit) and current density (i.e. thickness of the deposit and the rate of reduction of the $\mathrm{PbO}_{2}$ layer). During the earlier study [7] it was also shown that, above a critical $\mathrm{Pb}^{2+}$ concentration in the electrolyte, the deposit was a smooth, compact and uniform layer of $\alpha-\mathrm{PbO}_{2}$ but below the critical level, the layer became rougher and then lost material while the phase composition became a mixture of $\alpha-\mathrm{PbO}_{2}$ and $\beta-\mathrm{PbO}_{2}$; it could not be proved, however, that the change in structure of the deposit was caused by the change in phase composition. The build up of the lead on the negative electrode is a consequence only of a current efficiency below $100 \%$ arising from a limitation of the reduction of the $\mathrm{PbO}_{2}$ on the positive electrode in each cycle.

The voltage $v s$. time responses during the partial discharge experiments are also totally consistent with the concept of an increase in $\mathrm{pH}$ within the $\mathrm{PbO}_{2}$ layer during discharge if discharge is driven beyond a critical stage. During the initial cycles, see Fig. 11, the voltage during both charge and discharge are constant and attributable to an acidic environment for the reduction and deposition of $\mathrm{PbO}_{2}$ (it should be noted that the $\mathrm{Pb}^{2+} / \mathrm{Pb}$ potential is almost constant throughout charge and discharge and hence the changes in cell voltage are equivalent to a change in the positive electrode potential). After extended cycling, a negative shift in voltage is seen during discharge and charge occurs initially at less positive voltage with a shift to more positive potentials after a period of time. Both changes would be consistent with a less acidic, local environment occurring within the $\mathrm{PbO}_{2}$ layer during discharge after extended cycling. It was also found that the shifts in voltage were more pronounced with depth of discharge, charge time and discharge rate. Indeed, when short timescale charge/discharge cycling is undertaken, charge and discharge again occur at constant voltages [8]. Not surprisingly, the $\mathrm{pH}$ increase within the $\mathrm{PbO}_{2}$ layer is most pronounced when this layer is thick.

Of course, increasing the electrolyte volume to electrode area ratio in order to extend the cycle life is not a realistic option in an energy storage facility and the experiments with the small flow cell are included only to demonstrate that a soluble lead acid flow cell might be expected to perform satisfactorily even with higher rates of charge/discharge, ca. up to $100 \mathrm{~mA} \mathrm{~cm}^{-2}$, and longer charge times provided that the electrolyte composition, both locally and in the bulk electrolyte, can be maintained within specification. Clearly, long-term operation of the battery depends on a procedure to prevent the continuous build up of the solids on the electrodes. The ideal solution is to find a modification of the $\mathrm{PbO}_{2}$ layer structure that allows its complete reduction each cycle and this approach is the subject of planned work. The alternative is undertake electrode and/or electrolyte maintenance at regular intervals.

It is also recognised that an improvement in voltage efficiency would be beneficial to battery performance. The major contribution to the voltage efficiency being lower than in other battery systems is the relatively slow kinetics of the $\mathrm{Pb}^{2+} / \mathrm{PbO}_{2}$ couple. There appears to be an overpotential associated with the positive electrode reactions even when nucleation effects are excluded. There are, however, some indications in a recent paper [10] as well as in our own studies [7] that this overpotential would be much reduced if the $\mathrm{PbO}_{2}$ reduction can be achieved under more controlled conditions. In practice, a battery system might not be fully discharged on a routine basis.

\section{Acknowledgements}

The authors are grateful for financial support via a DTI Technology Programme (Contract TP/4/EET/6/I/2296) entitled 'Redox Flow Cells for Intelligent Grid Management'. The authors acknowledge gratefully the assistance of Mr. David Cardwell in the design and construction of the data monitoring and control electronics.

\section{References}

[1] A. Hazza, D. Pletcher, R. Wills, Phys. Chem. Chem. Phys. 6 (2004) 1773

[2] D. Pletcher, R. Wills, Phys. Chem. Chem. Phys. 6 (2004) 1779.

[3] D. Pletcher, R. Wills, J. Power Sources 149 (2005) 96.

[4] A. Hazza, D. Pletcher, R. Wills, J. Power Sources 149 (2005) 103.

[5] D. Pletcher, H. Zhou, G. Kear, C.T.J. Low, F.C. Walsh, R. Wills, J. Power Sources 180 (2008) 621 .

[6] D. Pletcher, H. Zhou, G. Kear, C.T.J. Low, F.C. Walsh, R. Wills, J. Power Sources 180 (2008) 630.

[7] X. Li, D. Pletcher, F.C. Walsh, Electrochim. Acta 54 (2009) 4688.

[8] R.G.A. Wills, J. Collins, D. Stratton-Campbell, C.T.J. Low, D. Pletcher, F.C. Walsh, J. Appl. Electrochem., in press, doi:101007/s10800-009r-r9815-4.

[9] J. Collins, D. Stratton-Campbell, F.C. Walsh, in preparation.

[10] H.Y. Peng, H.Y. Chen, W.S. Lu, S.J. Hu, H. Li, J.M. Nan, Z.H. Xu, J. Power Sources 168 (2007) 105. 